\title{
EKSISTENSI PRODI AGAMA LANGKA PEMINAT DI UIN AR RANIRY BANDA ACEH
}

\author{
Suprapto ${ }^{1}$ \\ ${ }^{1}$ Peneliti Puslitbang Pendidikan Agama dan Keagaman \\ supraptolitbang@yahoo.com
}

Received: 26/10/2018, Accepted: 20/02/2019, Published: 25/02/2019

\begin{abstract}
After the transition of IAIN status to UIN, the interest of the community to enter UIN is higher in general study programs such as IT, medicine, economics, and law. While for religious study programs that are related to the world of work (multidisciplinary Islamic study program) are also still relatively high, but for religious study programs with pure knowledge is very less interested. This study uses qualitative methods, through documentation study techniques by collecting and analyzing official documents, documents whose validity relates to rare study programs and in-depthinter view techniques. This study resulted in: 1) rare religious study programs interested in UIN Ar Raniry are Study Programs of Religion of Sharia Faculty and Law, Islamic Community Development Study Program of Da'wah and Communication Faculty, Aqidah Study Program and Islamic Philosophy Faculty of Ushuludin and Philosophy, Comparative Study Program of Sharia Faculty and Law and Diploma III Science Library of Humanities Faculty of Humanities. 2) rare study program alumni interested in working as employees in the Ministry of Religion, Religion Extension, Board Members, Regional Governments, TNI and Polri, Interpreneurship, Journalists, Writers and Ustadz. Among them there are those who are community leaders, figures and bureaucrats. 3) The large number of rare students interested is not important, the most important is students who have quality. Recommended: 1) The Ministry of Religion must maintain a rare religious study program interested in PTKI. 2) Need strategic and technical steps in the Aqidah and Islamic Philosophy (AFI) study program, through: The Chancellor's and Dean's policies pass students who are not accepted to other study programs with a standardized grade of graduation to enter the rare study program applicants; opened a special path "Achievement of art and sports science"; Empowering Lecturers, Community Leaders and Alumni to socialize religious studies in MA students; Vocational High School and Islamic Boarding School; MOU of Employment between ArIN Aririry UIN and Local Government in rare study programs interested; and Providing scholarships to students to study programs quietly interested.
\end{abstract}

Keywords: existence, rare religion, study program.

\begin{abstract}
ABSTRAK
Pasca peralihan status IAIN menjadi UIN, minat masyarakat untuk masuk UIN lebih tinggi pada prodi umum seperti IT, kedokteran, ekonomi, dan hukum. Sementara untuk program studi agama yang mempunyai kaitan dengan dunia kerja (prodi keislaman multidisipliner) juga masih relatif tinggi peminatnya, tetapi untuk prodi agama dengan keilmuan murni sangat kurang peminatnya. Penelitian ini menggunakan metode kualitatif, melalui teknik studi dokumentasi dengan menghimpun dan menganalisis dokumendokumen resmi, dokumen yang keabsahannya terkait dengan prodi langka peminat dan teknik wawancara mendalam (in-depth interview). Penelitian ini menghasilkan: 1) prodi agama langka peminat di UIN Ar Raniry adalah Prodi Studi Agama-Agama Fakultas Syariah
\end{abstract}




\section{Eksistensi Prodi Agama Langka Peminat...}

dan Hukum, Prodi Pengembangan Masyarakat Islam Fakultas Dakwah dan Komunikasi, Prodi Aqidah dan Filsafat Islam Fakultas Ushuludin dan Filsafat, Prodi Perbandingan Mazhab Fakultas Syariah dan Hukum dan Dploma III Ilmu Perpustakaan Fakultas Adab Humaniora. 2) Alumni Prodi langka peminat bekerja sebagai karyawan di Kemenag, Penyuluh Agama, Anggota Dewan, Pemerintahan Daerah, TNI dan Polri, Interpreneurship, Wartawan, Penulis, dan mejadi Ustadz. Di antara mereka ada yang menjadi Tokoh Masyarakat, tokoh dan birokrat. 3) Besarnya jumlah mahasiswa langka peminat tidak penting, yang terpenting adalah mahasiswa yang memiliki kualitas. Direkomendasikan: 1) Kementerian Agama harus tetap mempertahankan program studi keagamaan langka peminat di PTKI. 2) Perlu langkah-langkah strategis dan teknis pada program studi Aqidah dan Filsafat Islam (AFI), melalui: Kebijakan Rektor dan Dekan meluluskan mahasiswa yang tidak diterima pada prodi lain dengan standar nilai lulus untuk masuk pada prodi langka peminat; membuka jalur khusus "Prestasi science seni dan olah raga"; memberdayakan dosen, tokoh masyarakat, dan alumni untuk mensosialisasikan program studi agama-agama pada siswa MA; SMA/SMK, dan Pondok Pesantren; MOU lapangan pekerjaan antara UIN Ar Raniry dengan Pemerintah Daerah pada prodi langka peminat; dan memberikan beasiswa kepada mahasiswa pada prodi sepi peminat.

\section{A. PENDAHULUAN}

Perubahan bentuk IAIN menjadi UIN karena rendahnya minat calon mahasiswa baru yang memilih melanjutkan belajarnya ke IAIN, di samping alasan filosofis untuk menghilangkan dikotomi keilmuan antara ilmu-ilmu keislaman dengan ilmu-ilmu umum. Seiring dengan perubahan ini muncul perdebatan di antaranya terkait kekhawatiran akan terpinggirkannya program studi agama dan kalah bersaing dengan program studi yang mempelajari bidang keilmuan umum. Jika ini terjadi, maka akan mengerdilkan keilmuan agama yang pada awalnya menjadi tugas utama sebelum adanya perubahan bentuk institusi.

\section{Dalam konteks Perguruan Tinggi} Keagamaan Islam (PTKI), variannya terdiri atas: Universitas, Institut, dan
Sekolah Tinggi. Jumlahnya sebanyak 700 buah perguruan tinggi, dengan 643 perguruan tinggi berstatus swasta, dan 57 buah berstatus negeri, tersebar mulai dari Aceh hingga Papua. ${ }^{1}$ Dari jumlah tersebut, 17 buah di antaranya berstatus sebagai Universitas Islam Negeri (UIN). ${ }^{2}$ Sedangkan jika dilihat dari jumlah program studi, perbandingan program studi agama dan prodi umum: total prodi (954), dengan jumlah prodi agama sebanyak 722 (75,68\%), sementara jumah prodi umum sebanyak 232 (24,32\%). Pada PTKI UIN terdapat $163(53,8 \%)$ prodi agama, dan 138 (45,54\%) prodi umum. Pada IAIN, terdapat $300(82,64 \%)$ prodi agama, dan $57(15,7 \%)$ prodi umum. Pada

\begin{tabular}{lccc}
\hline 1 & Statistik Pendidikan & Islam, & Tahun \\
$2014 / 2015$, hlm. 308. & & \\
2 Statistik Pendidikan & Islam, & Tahun \\
2014/2015, hlm. 309. & &
\end{tabular}


STAIN, terdapat $259(86,62 \%)$ prodi agama, dan 37 (12,37\%) prodi umum (Puslitbang Pendidikan Agama dan Keagamaan, 2013). Di antara program studi agama yang ada masih dapat dikelompokkan ke dalam dua varian program studi, yakni program studi agama dengan keilmuan multidisipliner dan program studi agama dengan keilmuan murni.

Permasalahannya, dalam konteks minat, beberapa kajian menyebutkan bahwa pasca peralihan status IAIN menjadi UIN, minat masyarakat untuk masuk UIN lebih tinggi pada prodi umum seperti IT, kedokteran, ekonomi, dan hukum. Sementara untuk program studi agama yang mempunyai kaitan dengan dunia kerja (prodi keislaman multidisipliner) juga masih relatif tinggi peminatnya, tetapi untuk prodi agama dengan keilmuan murni sangat kurang peminatnya. Ini dibuktikan dengan diberikannya afirmasi di antaranya melalui beasiswa dan cara lainnya untuk dapat menarik minat calon mahasiswa.

Hasil riset Puslitbang Peda, animo masyarakat untuk studi di UIN dalam 3 (tiga) tahun terakhir (pada saat riset dilakukan) mengalami peningkatan sebesar $164 \%$, minat terhadap "Prodi Agama" (Adab, Dakwah, Syari'ah, Ushuluddin, dan Tarbiyah) juga meningkat hingga 154
\%, bahkan kualitas "Prodi Umum" (Sainsteknologi, Kedokteran, dan Ilmuilmu Sosial Humaniora) juga semakin on the right track dan peminatnya meningkat hingga $176 \%{ }^{3}$ Untuk mendapatkan informasi dan data yang komprehensif, terkait eksistensi prodi keagamaan murni di PTKI, maka penelitan ini penting dilakukan.

Penelitian ini bertujuan untuk mengetahui eksistensi prodi agama dengan keilmuan murni di UIN seluruh Indonesia; minat masyarakat/siswa jenjang menengah/mahasiswa terhadap prodi agama di PTKI; sebaran dan kiprah alumni prodi agama dengan keilmuan murni di dunia kerja; dan kebijakan perguruan tinggi untuk mempertahankan eksistensi prodi keilmuan murni di UIN.

Metode penelitian yang digunakan dalam penelitian ini adalah metode kualitatif, melalui: pertama, teknik studi dokumentasi dengan menghimpun dan menganalisis dokumen-dokumen resmi, dokumen yang keabsahannya terkait dengan prodi langka peminat. Kedua, teknik wawancara mendalam (indepthinterview) dengan memakai jenis wawancara semi struktur (semistructure interview), di mana peneliti mengupayakan pendapat dan ide-ide narasumber secara

Puslitbang Penda. (2013). Eksekutif Summary Penelitian Pemetaan Kapasitas 6 UIN. Jakarta: Balitbang Kemenag. 


\section{Eksistensi Prodi Agama Langka Peminat...}

lebih terbuka agar permasalahan menjadi jelas. Peneliti perlu mendengarkan secara teliti dan mencatat atau merekam apa yang dikemukakan oleh narasumber.

Penelitian ini berguna untuk pengambilan kebijakan dalam mempertahankan dan pengembangan prodi agama dengan keilmuan murni di UIN Seluruh Indonesia, baik yang dilakukan oleh masing-masing perguruan tinggi maupun oleh kementerian agama dalam hal ini direktorat pendidikan tinggi keagamaan Islam.

\section{B. KAJIAN TEORITIK}

\section{Eksistensi Prodi Agama}

Seiring dengan respon masyarakat dalam menyikapi perkembangan ilmu pengetahuan dan teknologi, dan juga untuk menghilangkan pemikiran dikotomis yang terjadi selama ini, antara ilmu-ilmu keislaman dan imu-ilmu umum, maka diajukan perubahan bentuk institusi dari Institut Agama Islam Negeri (IAIN) dengan bidang keilmuan keagamaan Islam menjadi Universitas Islam Negeri (UIN) sehingga dapat membukan program studiprogram studi umum. Perubahan awal dimulai dengan UIN Syarif Hidayatullah Jakarta, UIN Sunan Kalijaga Yogyakarta, UIN Malik Ibrahim Malang, dan UIN Syarif Qasim Riau. Selanjutnya disusul oleh IAIN-IAIN lainnya yang meninta perubahan bentuk institusi, sehingga saat ini berkembang menjadi 17 UIN di seluruh Indonesia.

Perubahan IAIN menjadi UIN diikuti oleh pengembangan metafora dan simbol tertentu. Hal tersebut dimaksudkan untuk menunjukkan status dan posisi ilmu pengetahuan umum pada satu sisi dan ilmu pengetahuan Islam pada sisi lainnya. Pada UIN Syarif Kasim Riau dikenal konsep "Membangun Ilmu Paradigma Islam". Pada UIN Syarif Hidayatullah (Syahid) dikenal konsep "Integrasi Ilmu-ilmu". Pada UIN Sunan Gunung Djati Bandung dikenal konsep "Wahyu Memandu Ilmu". Pada UIN Sunan Kalijaga Yogyakarta, dikenal konsep "Integrasi-Interkoneksi". Pada UIN Malang dikenal konsep "Pohon Ilmu". Pada UIN Alauddin Makassar dikenal konsep "Pohon Cemara". 4

Dengan perubahan bentuk institusi tersebut, menurut Nur Syam, maka ada tiga bentuk prodi yang dikelola oleh UIN yaitu: Prodi ilmu keislaman murni, prodi ilmu keislaman mutidisipliner, dan prodi ilmu umum. Berdasarkan hasil pemetaan, lebih lanjut Nur Syam menyatakan, bahwa dalam kasus UIN Sunan Ampel Surabaya perbandingannya prodi keislaman murni sebanyak 30\%, prodi keagamaan multidisipliner $44 \%$, dan prodi umum

\footnotetext{
${ }^{4}$ Puslitbang Penda. 2013. Laporan Penelitian Kapasitas 6 UIN. Jakarta: Balitbang Kemenag.
} 
26\%. ${ }^{5}$ Pada UIN dan PTKI lainnya, tentu punya proporsi yang berbeda, dengan varian dan nama prodi yang berbeda. Ini bergantung pada kapasitas SDM pengajar dan ilmuwan yang dimiliki, serta pada tuntutan serta kebutuhan lingkungan sekitar. Dalam konteks program studi agama di PTKI, saat ini telah ada 55 varian program studi (agama) yang eksistensinya berbeda dengan program studi (umum atau non-agama), baik penyebutan ataupun substansinya. ${ }^{6}$

\section{Konsep Manajemen}

Manajemen memiliki kunci utama dalam organisasi dalam mengatur, mengkoordinasikan kegiatan-kegiatan subsub sistem dan menghubungkannya dengan lingkungan. Dengan kata lain manajemen merupakan proses di mana sumber-sumber yang ada diintegrasikan menjadi suatu system untuk mencapai tujuan. Sedangkan manajer akan bertanggung jawab dalam mengintegrasikan unsur-unsur manusia, mesin, dan uang dan lain-lain menjadi produktif. Manajer berupaya mengkoordinasikan kegiatan-kegiatan ke arah pencapaian tujuan-tujuan sistem organisasi.

\footnotetext{
${ }^{5}$ Nur Syam. Menyeimbangkan Prodi Agama dan umum, http://nursyam.uinsby.ac.id/?p=832.

6 PMA No. 37 Tahun 2017. tentang Perubahan atas Peraturan Menteri Agama No. 33 Tahun 2016 tentang Gelar Akademik Perguruan Tinggi Keagamaan.
}

Ada dua jenis pendekatan yang dapat digunakan untuk mempelajari manajemen, pertama, memperlihatkan proses-proses administratif, yang terdiri dari; perencanaan, pengorganisasian, dan pengawasan untuk mencapai tujuan-tujuan organisasi. Kedua, mempelajari sub sistem organisasi, yang meliputi tugas-tugas strategis, koordinasi, dan operasi. Strategi, menghubungkan organisasi dengan lingkungan dan mendesain secara komprehensif sistem dan rencana. Koordinasi, mengintegrasikan kegiatankegiatan di dalam organisasi. Operasi, melaksanakan pencapaian tujuan-tujuan secara efektif dan efisien.

Dalam melaksanakan tugas-tugas tersebut dibutuhkan sistem lingkungan, perspektif waktu, pendapat, proses umum, dan teknik membuat keputusan. Manajemen dalam organisasi merupakan koordinasi usaha kelompok untuk mencapai tujuan yang telah ditetapkan sebelumnya. Koordinasi itu terutama dipengaruhi oleh: (1) melalui orang-orang, (2) lewat teknikteknik, (3) di dalam suatu organisasi, dan (4) ke arah tujuan-tujuan. Pada pokoknya manajemen adalah proses pengintegrasian sumber-sumber manusiawi dan material ke dalam suatu sistem keseluruhan untuk mencapai tujuan. $^{7}$

\footnotetext{
${ }^{7}$ Konsep Manajemen Pendidikan $~$ Kumpulan Makalah \& Artikelhttps:// makalahibnu.blogspot.com/ 2010/01/konsep-manajemen
} 


\section{Eksistensi Prodi Agama Langka Peminat...}

\section{Tujuan dan Manfaat Manajemen Pendidikan}

Tujuan dan manfaat manajemen pendidikan antara lain sebagai berikut:

a. Terwujudnya suasana belajar dan proses pembelajaran yang aktif, inovatif, kreatif, efektif, dan menyenangkan (PAIKEM).

b. Terciptanya peserta didik yang aktif.

c. Terpenuhinya salah satu dari empat kompetensi tenaga pendidik dan kependidikan (tertunjangnya kompetensi profesional sebagai pendidik dan tenaga kependidikan sebagai manajer).

d. Tercapainya tujuan pendidikan secara efektif dan efisien.

e. Terbekalinya tenaga kependidikan dengan teori tentang proses dan tugas administrasi pendidikan (tertunjangan profesi sebagai manajer atau konsultan manajemen pendidikan).

f. Teratasinya masalah mutu pendidikan. ${ }^{8}$

\section{Fungsi Manajemen Pendidikan}

Manajemen pendidikan mempunyai fungsi yang terpadu dengan proses pendidikan khususnya dengan pengelolaan

pendidikan.html \#ixzz5UDaEnf5h, diakses pada tanggal 17 Oktober 2018.

${ }^{8}$ Didin Kurniadin dan Imam Machali. (2012). Manajemen Pendidikan Konsep dan Prinsip Pengelolaan Pendidikan. Jogjakarta: Ar-Ruzz Media. hlm. 125 proses pembelajaran. Dalam hubungan ini, terdapat beberapa fungsi manajemen pendidikan, sebagai berikut:

a. Fungsi perencanaan, mencakup berbagai kegiatan menentukan kebutuhan, penentuan strategi pencapaian tujuan, menentukan isi program pendidikan, dan lain-lain.

b. Fungsi organisasi, meliputi pengelolaan ketenagaan, sarana dan prasarana, distribusi tugas dan tanggung jawab dalam pengelolaan secara integral.

c. Fungsi koordinasi, yang berupaya menstabilisasi antara berbagai tugas, tanggung jawab dan kewenangan untuk menjamin pelaksanaan dan keberhasilan program pendidikan.

d. Fungsi motifasi (penggerakan), yang dimaksudkan untuk meningkatkan efisiensi proses dan keberhasilan program pelatihan.

e. Fungsi control, yang berupaya melakukan pengawasan, penilaian, monitoring, perbaiakan terhadap kelemahan-kelemahan dalam sistem manajemen pendidikan tersebut. ${ }^{9}$ 


\section{Model Evaluasi CIPP}

Untuk mengetahui pelaksanaan program pada sasaran penelitian ini dilakukan dengan menggunakan model evaluasi CIPP. Model evaluasi CIPP adalah model evaluasi yang terdiri dari empat komponen evaluasi yaitu Context, Input, Process, dan Product (CIPP). CIPP merupakan singkatan dari context evaluation artinya evaluasi terhadap context, input evaluation artinya evaluasi terhadap masukan, process evaluation artinya evaluasi terhadap process, dan product evaluation artinya evaluasi terhadap hasil.

\section{Context Evaluation (Evaluasi} Konteks) yang utama adalah untuk mengetahui kekuatandan kelemahan yang dimiliki evaluasi. Input Evaluation (Evaluasi Masukan) membantu mengatur keputusan, menentukan sumber-sumber yang ada, alternatife apa yang diambil, apa rencana dan strategi untuk mencapai tujuan, dan bagaimana prosedur kerja untuk mencapainya. Komponen evaluasi masukan meliputi: 1) Sumber daya manusia, 2) Sarana dan peralatan pendukung, 3) Dana atau anggaran, dan 4) Berbagai prosedur dan aturan yang diperlukan. Process Evaluation (Evaluasi Proses) digunakan untuk mendeteksi atau memprediksi rancangan prosedur atau rancangan implementasi selama tahap implementasi, menyediakan informasi untuk keputusan program dan sebagai rekaman atau arsip prosedur yang telah terjadi. Product Evaluation (Evaluasi Produk/Hasil) untuk membantu membuat keputusan selanjutnya, baik mengenai hasil yang telah dicapai maupun apa yang dilakukan setelah program itu berjalan. ${ }^{10}$

\section{PROFIL UIN AR RANIRY BANDA ACEH}

\section{Sejarah}

IAIN adalah singkatan dari Institut Agama Islam Negeri dan kata Ar Raniry yang dinisbahkan kepada IAIN Banda Aceh adalah nama seorang ulama besar dan mufti yang sangat berpengaruh pada masa Sultan Iskandar Tsani (memerintah tahun 1637-1641). Ulama besar tersebut nama lengkapnya Syeikh Nuruddin Ar Raniry yang berasal dari Ranir (sekarang Rander) di Gujarat, India. Beliau telah memberikan konstribusi yang amat berharga dalam pengembangan pemikiran Islam di Asia Tenggara khususnya di Aceh

Tepat pada 5 Oktober 2013 genap berumur 50 tahun, Perguruan Tinggi ini akan merubah namanya dari Institut menjadi Universitas melalui PERPRES No. 64 Tahun 2013 dan mulai berlaku

10 https://dinarpratama.wordpress. com/ 2010/11/20/model-evaluasi- cipp-context-inputprocess- product/, diakses pada tanggal 18 Oktober 2018 . 


\section{Eksistensi Prodi Agama Langka Peminat...}

pada tanggal 1 Oktober 2013 dengan nama Universitas Islam Negeri Ar Raniry (UIN Ar Raniry).

Dengan demikian maka mulai 1 Oktober 2013 juga nama IAIN Ar Raniry mulai terhapus secara legalitas, dan lama kelamaan juga akan terhapus sedikit demi sedikit dari dalam hati masyarakat Aceh secara khusus, dan masyarakat Indonesia, serta masyarakat lainnya di belahan dunia secara umum.

Dalam perkembangannya, UIN $\mathrm{Ar}$ Raniry, terus membenahi diri dengan membuka sejumlah program studi yang sesuai dengan kebutuhan masyarakat. Tidak hanya itu dalam upaya penyempurnaan keberadaannya, lembaga ini juga telah membuka program magister (S2) pada tahun 1089 dan perogram doctoral (S3) pada tahun 2002. Dengan adanya program studi strata 1 sampai strata 3 lembaga ini diharapkan akan melahirkan para pendidik, da'i, pemikir dan ulama yang professional dan sesuai dengan perkembnagn dan perubahan jaman.

Visi UIN Ar-Raniry "Menjadi Universitas yang unggul dalam pengembangan dan pengintegrasian, ilmu keislaman, sains, teknologi dan seni”. Sedangkan Misinya adalah 1) Melahirkan sarjana yang memiliki kemampuan akademik, profesi dan atau vokasi yang kompetitif, berorientasi pada masa depan dan beraklak mulia; 2) Mengembangkan tradisi riset yang multidisipliner dan integratif berbasis syariat islam; 3) Mengimplementasikan ilmu untuk membangun masyarakat madani, yang beriman, berilmu dan beramal.

\section{Keadaan Mahasiswa}

Jumlah mahasiswa UIN Ar Raniry Tahun Akademik 2017/2018 adalah sebanyak 5.708 mahasiswa, dengan rincian: Fakultas Syariah sebanyak 801 orang; Fakultas Tarbiyah dan Keguruan 1.844 orang; Fakultas Ushuludin sebanyak 315 orang, Fakultas Dakwah dan Komunikasi sebanyak 452 orang, Fakultas Adab dan Humaniora sebanyak 374 orang; Fakultas Psikologi sebanyak 210 orang; Fakultas Ilmu Sosial dan Pemerintahan sebanyak 309 orang; Fakultas Ekonomi dan Bisnis Islam sebanyak 748 orang; dan Pascasarjana S2 (167 orang), serta S3 (51 orang).

\section{Keadaaan Tenaga Dosen}

Dosen UIN Ar Raniry Banda Aceh seluruhnya berjumlah 418 orang terdiri dari 408 orang dari Fakultas dan 10 orang Dosen DPK. Secara rinci dapat disampaikan jumlah dosen Fakultas Syariah dan Hukum berjumlah 52 orang $(\mathrm{S} 1=4, \mathrm{~S} 2=31, \mathrm{~S} 3=27)$; Fakultas Tarbiyah dan Keguruan berjumlah 151 orang $(\mathrm{S} 1=8$, S2=113, S3=30); Fakultas Ushuludin berjumlah 42 orang $(\mathrm{S} 1=6, \mathrm{~S} 2=28, \mathrm{~S} 3=8)$; 
Fakultas Dakwah dan Komunikasi berjumlah 54 orang $(\mathrm{S} 1=2, \mathrm{~S} 2=47, \mathrm{~S} 3=5)$; Fakultas Adab berjumlah 45 orang (S2=37, S3=8); Fakultas Psikologi berjumlah 7 orang (S1=3, S2=4); Fakultas Ilmu Sosial dan Pemerintahan berjumlah 3 orang $(\mathrm{S} 2=3)$; Fakultas Ekonomi dan Bisnis Islam berjumlah 21 orang $(\mathrm{S} 1=1$, S2=15, S3=5); Fakultas Sains dan Teknologi berjumlah 33 orang $(\mathrm{S} 2=30$, S3=3), dan Dosen DPK berjumlah 10 orang $(\mathrm{S} 1=1, \mathrm{~S} 2=8, \mathrm{~S} 3=1)$. $^{11}$

\section{Keadaan Tenaga Administrasi}

Tenaga Administrasi UIN Ar Raniry Banda Aceh seluruhnya berjumlah 215 orang terdiri dari Biro Administrasi Akademik dan Kemahasiswaan (16 orang); Biro Administrasi Umum (25 orang; Fakultas Syariah dan Hukum (30 orang); Fakultas Tarbiyah dan Keguruan (42 orang); Fakultas Ushuludin dan Filsafat (14 orang); Fakultas Dakwah dan Komunikasi (15 orang); Fakultas Adab dan Humaniora (17 orang); Fakultas Psikologi (5 orang); Fakultas Ilmu Sosial dan Pemerintahan (4 orang); Fakultas Ekonomi dan Bisnis Islam (3 orang); Fakultas Sains dan Teknologi (4 orang); Program Pasca sarjana (11 orang); Lembaga Penelitian (4 orang); Lembaga Pengabdian Masyarakat (4 orang); Pusat Bahasa (3 orang); Pusat Informasi dan 2017.
Komputer (5 orang); Pustakawan (8 orang); Lembaga Penjamin Mutu (3 orang); PSGA (2 orang); dan SPI (2 orang). ${ }^{12}$

\section{Keadaan Sarana dan Prasarana}

Sarana dan Prasarana yang tersedia dalam menunjang pendidikan di UIN Ar Raniry Banda Aceh terdiri dari masjid; mushala; perpustakaan; gedung pusat kegiatan mahasiswa laboratorium; sport venue (lapangan bola kaki, lapangan basket dan panjat tebing); poliklinik; dan museum.

\section{PRODI AQIDAH DAN FILSAFAT ISLAM}

Prodi Aqidah dan Filsafat Islam UIN Ar Raniry Banda Aceh merupakan program studi unggulan yang dimiliki Fakultas Ushuludin dan Filsafat UIN Ar Raniry. Prodi Aqidah dan Filsafat Islam ini merupakan perwujudan baru dari Jurusan Aqidah Filsafat yang telah berdiri sejak tahun 1974. Dalam kiprahnya program studi ini telah melahirkan ratusan sarjana yang kini bekerja di berbagai sektor pekerjaan baik negeri maupun swasta. Secara konstitusional Prodi Aqidah dan Filsafat Islam hadir untuk memperkenalkan khazanah keilmuan Islam secara komprehensif meliputi kajian kalam (teologi), filsafat, tasawuf, dan

\footnotetext{
${ }^{12}$ Profil UIN Ar Raniry Banda Aceh, Tahun 2017.
} 


\section{Eksistensi Prodi Agama Langka Peminat...}

pemikiran Islam baik klasik maupun kontemporer.

Kompetensi Program Studi Aqidah dan Filsafat Islam ini diproyeksikan untuk melahirkan lulusan yang mempunyai kemampuan akademik, futuristic, berdaya saing dengan landasan aqidah Islamiyah dan berakhlak mulia. Memiliki wawasan keislaman yang luas sebagai sosok cendekiawan muda muslim yang mampu mejawab persoalan keagamaan yang muncul dalam masyarakat. Mempunyai keahlian/skill melakukan riset ilmiah sebagai peneliti muda yang handal.

Visi Prodi Aqidah dan Filsafat Islam adalah "Menjadi Program Studi terkemuka dalam kajian Aqidah dan Filsafat Islam dengan pendekatan integratif dan interdisipliner di Indonesia pada tahun 2025”. Sedangkan Misinya: 1). Melahirkan sarjana yang memiliki kemampuan akademik, futuristik, berdaya saing, dan berakhlak mulia; 2) Mengembangkan kajian Aqidah dan Filsafat Islam berbasis riset ilmiah melalui pendekatan integratif dan interdisipliner; 3) Mengimplementasikan dan mempublikasikan hasil-hasil riset Aqidah dan Filsafat Islam dalam rangka pengadaan pengetahuan dan mewujudkan masyarakat madani yang inklusif; 4) Menjalin kemitraan Prodi dengan berbagai pihak yang produktif dan inovatif dalam mewujudkan tridarma perguruan tinggi.

Jumlah mahasiswa Prodi Aqidah dan Filsafat Islam Tahun Akademik 2018/2019 seluruhnya berjumlah 246 orang. Secara rinci jumlah kouta, pendaftar, diterima dan jumlah mahasiswa tiga tahun terakhir sebagai berikut:

Jumlah kuota mahasiswa tiga tahun terahir: $\quad 2016 / 2017=80 \quad$ orang, $2017 / 2018=80 \quad$ orang, $\quad 2018 / 2019=80$ orang. Jumlah pendaftar tiga tahun terakhir: $\quad 2016 / 2017=67 \quad$ orang $2017 / 2018=92 \quad$ orang, $\quad 2018 / 2019=59$ orang. Jumlah mahasiswa yang diterima: $2016 / 2017=32 \quad$ orang, $\quad 2017 / 2018=61$ orang, dan 2018/2019=48 orang. Jumlah mahasiswa tiga tahun terahir: $2016 / 2017=155$ orang, $2017 / 2018=213$ orang, $2018 / 2019=246$ orang.

Jumlah dosen Prodi Aqidah dan Filsafat Islam seluruhnya berjumlah 14 (empat belas) orang terdiri dari satu guru besar, sepuluh doktor dan tiga kandidat doktor. Sedangkan staf administrasi berjumlah satu orang

Kurikulum Prodi Aqidah dan Filsafat Islam UIN Ar Raniry Banda Aceh mengacu pada visi, misi, dan tujuan Program Studi AFI yang berbasis pada KKNI. Penyebaran mata kuliah Program Studi Aqidah dan Filsafat Islam tersebut di atas, maka rmata kuliah inti pada program 
studi ini adalah Studi Syariah Islam; Filsafat Hukum Islam; Filsafat Islam Klasik; Filsafat Islam Modern; Epistimologi Islam 1 dan 2; Metodologi Penelitian Filsafat; Ilmu Kalam Modern;

Ilmu Kalam Klasik; Orientalisme dan Oksidentalisme; Pemikiran Islam Nusantara; Filsafat Nilai; Filsafat Manusia*); Filsafat Kebudayaan*); Filsafat ke Tuhanan*); Filsafat Politik; Hermunetika Islam; Ontologi Metafisika; Islam dan Modernitas; Pengantar Tasawuf; Tasawuf Akhlaki; Tasawuf Faksafi; Studi Naskah Ilmu Tasawuf*); Studi Naskah Filsafat Islam*); Tasawuf; dan Psikoterapi dan Psikologi Agama.*) optional.

Mahasiswa Prodi Aqidah dan Filsafat Islam terkoneksi dengan semua fasilitas yang ada di kampus UIN Ar Raniry, seperti Perpustakaan, pusat pengembangan bahasa asing, mahad ali, pusat kegiatan mahasiswa, pusat kegiatan olahraga, pusat layanan kesehatan dan asrama mahasiswa. Di samping itu, tersedia sarana lain seperti kantor, ruang kuliah, masjid, jaringan internet, toilet, dan lain-lain.

\section{E. PRODI AGAMA LANGKA PEMINAT 3 TAHUN TERAKHIR IAIN dan 3 TAHUN TERAKHIR UIN}

IAIN Ar Raniry Banda Aceh menjadi Universitas Islam Negeri Ar Raniry sesuai dengan PERPRES No. 64 Tahun 2013 tertanggal 1 Oktober 2013. Seiring dengan perubahan tersebut jumlah mahasiswa mengalami perubahan baik pada fakultas dan program studi. Berikut dirapatkan jumlah calon mahasiswa (peminat) dan jumlah mahasiswa (diterima) tiga tahun terakhir pada saat peralihan IAIN menjadi UIN dan pada saat UIN.

Berdasarkan data tahun 2011 terlihat jumlah peminat cukup besar (2.532 orang) dan yang diterima (1.727 orang) selisihnya tidak diterima. Lima program studi yang paling diminati adalah Prodi Pendidikan Bahasa Inggris Fakultas Tarbiyah dan Keguruan (231 orang) diikuti secara berurutan Prodi Muamalat Fakultas Syariah dan Hukum (185 orang), Prodi Pendidikan Agama Islam Fakultas Tarbiyah dan Keguruan (183 orang), Prodi Pendidikan Bahasa Arab Fakultas Tarbiyah dan Keguruan (172 orang), dan Prodi Ilmu Perpustakaan Fakultas Adab dan Humaniora (111 orang). Sebaliknya lima prodi yang kurang peminat adalah Prodi Perbandingan Agama Fakultas Ushuludin dan Filsafat (52 orang), diikuti secara berurutan Prodi Sejarah dan Kebudayaan Islam Fakultas Adab dan Humaniora (59 orang), Prodi Diploma III Ilmu Perpustakaan Fakultas Adab dan Humaniora (64 orang), Prodi Komunikasi dan Penyiaran Islam Fakultas Dakwah dan Komunikasi (76 orang), dan Prodi Bahasa 


\section{Eksistensi Prodi Agama Langka Peminat...}

dan Sastra Arab Fakultas Adab dan Humaniora (83 orang).

Berdasarkan data tahun 2012 terlihat jumlah peminat cukup besar (3.595 orang) dan yang diterima (2.798 orang) selisihnya tidak diterima. Lima program studi yang paling diminati adalah Prodi Muamalat Fakultas Syariah dan Hukum (238 orang) diikuti secara berurutan Prodi Pendidikan Agama Islam Fakultas Tarbiyah dan Keguruan (271 orang), Prodi Komunikasi dan Penyiaran Islam Fakultas Dakwah dan Komunikasi (196 orang), Prodi Ilmu Perpustakaan Fakultas Adab dan Humaniora (192 orang), dan Prodi Pendidikan Biologi Fakultas Tarbiyah dan Keguruan (185). Sebaliknya Prodi yang kurang peminat secara berurutan adalah Prodi Aqidah dan Filsafat Fakultas Ushuludin dan Filsafat (39 orang), Prodi Perbandingan Agama (45 orang), Pengembangan Masyarakat Islam Fakultas Dakwah dan Komunikasi (58 orang), Prodi Diploma III Ilmu Perpustakaan Fakultas Adab dan Humaniora (72 orang), dan Prodi Bahasa dan Sastra Arab Fakultas Adab dan Humaniora (99).

Berdasarkan data tahun 2013 terlihat bahwa jumlah peminat cukup besar (3.610 orang) dan yang diterima (2.588 orang) selisihnya tidak diterima. Lima program studi yang paling diminati adalah Prodi Pendidikan Agama Islam Fakultas
Tarbiyah dan Keguruan (256 orang) diikuti secara berurutan Prodi Pendidikan Guru MI Fakultas Tarbiyah dan Keguruan (208 orang), Prodi Muamalat Fakultas Syariah dan Hukum (245 orang), Prodi Pendidikan Biologi Fakultas Tarbiyah dan Keguruan (191 orang), dan Prodi Ilmu Perpustakaan Fakultas Adab dan Humaniora (94 orang). Sebaliknya Prodi yang kurang peminat secara berurutan adalah Prodi Aqidah dan Filsafat Fakultas Ushuluddin (41 orang), Prodi Perbandingan Agama Fakultas Ushuludin dan Filsafat (42 orang), Prodi Pengembangan Masyarakat Islam Fakultas Dakwah dan Komunikasi (62 orang), Prodi Diploma III Ilmu Perpustakaan Fakultas Adab dan Humaniora (85 orang) (94 orang), dan Prodi Bahasa dan Sastra Arab Fakultas Adab dan Humaniora.

Berdasarkan data tahun 2015 Penerimaan Mahasiswa Baru pada seluruh Fakultas dan Prodi UIN Ar Raniry Banda Aceh menunjukkan bahwa jumlah peminat pada 43 Program Studi di sembilan Fakultas berdasarkan pilihan 1, 2, dan 3 sebanyak 2.613 orang, yang diterima 462 orang dan yang tidak diterima 2.151 orang. Jumlah peminat terbanyak secara berurutan adalah Prodi Perbankan Syariah Fakultas Ekonomi dan Bisnis Islam (373 orang), Prodi Ekonomi Syariah Fakultas Ekonomi dan Bisnis Islam (284 orang), Prodi Ilmu Hukum Fakultas Syariah dan 
Hukum (123 orang), Prodi Psikologi Fakultas Psikologi (124 orang), dan Prodi Ilmu Administrasi Negara Fakultas Ilmu Sosial dan pemerintahan (109 orang). Sebaliknya Prodi yang kurang peminat secara berurutan adalah Prodi Filsafat Agama dan Ilmu Aqidah Fakultas Ushuludin (4 orang), Prodi Pengembangan Masyarakat Islam Fakultas Dakwah dan Komunikasi (6 orang), Prodi Ilmu Perbandingan Agama Fakultas Ushuludin dan Filsafat (10 orang), dan Prodi Sosiologi Agama Fakultas Ushuludin dan Filsafat (14 orang).

Berdasarkan data tahun 2016 penerimaan mahasiswa baru pada seluruh Fakultas dan Prodi UIN Ar Raniry Banda Aceh menunjukan bahwa jumlah peminat pada 43 Program Studi di sembilan Fakultas berdasarkan pilihan 1, 2, dan 3 sebanyak 13.446 orang, diterima 2.832 orang dan yang tidak diterima (10.614 orang). Jumlah peminat terbesar secara berurutan adalah Prodi Perbankan Syariah Fakultas Ekonomi dan Bisnis Islam (1.845 orang), Prodi Hukum Ekonomi Syariah Fakultas Syariah dan Hukum (1.344 orang), Prodi Ekonomi Syariah Fakultas Ekonomi dan Bisnis Islam (1.242 orang), Prodi Ilmu Administrasi Negara fakultas Ilmu Sosial dan Pemerintahan (745 orang), dan Prodi Psikologi Fakultas Psikologi (636 orang). Sebaliknya Prodi yang kurang peminat secara berurutan adalah Prodi Perbandingan Mazhab Fakultas Syariah dan Hukum (11 orang), Prodi Ilmu Perbandingan Agama Fakultas Ushuludin dan Filsafat (17 orang), Prodi Filsafat Agama Fakultas Ushuludin dan Filsafat (18 orang), Prodi Pengembangan Masyarakat Islam Fakultas Dakwah dan Komunikasi (31 orang), dan Prodi Ilmu Aqidah Fakultas Ushuludin dan Filsafat (49 orang).

Berdasarkan data tahun 2017 penerimaan mahasiswa baru pada seluruh Fakultas dan Prodi UIN Ar Raniry Banda Aceh menunjukkan bahwa jumlah peminat pada 43 Program Studi di sembilan Fakultas berdasarkan pilihan 1, 2, dan 3 sebanyak 19.157 orang, diterima 3.315 orang dan yang tidak diterima 15.842. Jumlah mahasiswa terbanyak yang diterima secara berurutan adalah Prodi Perbankan Syariah Fakultas Ekonomi dan Bisnis Islam (2.756 orang), Prodi Hukum Ekonomi Syariah Fakultas Syariah dan Hukum (1.931 orang), Prodi Ekonomi Syariah Fakultas Ekonomi dan Bisnis Islam (1.866 orang), Prodi Ilmu Administrasi Negara Fakultas Ilmu Sosial dan Pemerintahan (1.271 orang), dan Prodi Psikologi Fakultas Psikologi (829 orang). Sebaliknya Prodi yang kurang peminat secara berurutan adalah Prodi Perbandingan Mazhab Fakultas Ushuludin 


\section{Eksistensi Prodi Agama Langka Peminat...}

dan Filsafat (19 orang), Prodi Prodi Perbandingan Agama Fakultas Syariah dan Hukum (22 orang), Prodi Pengembangan Masyarakat Islam Fakultas Dakwah dan Komunikasi (39 orang), Prodi Aqidah dan Filsafat Agama Fakultas Ushuludin dan Filsafat (92 orang), dan Prodi Pendidikan Bahasa Arab Fakultas Tarbiyah dan Keguruan (146 orang).

Berdasarkan data jumlah peminat calon mahasiswa pada berbagai program studi agama tersebut di atas selama tiga tahun terakhir pada saat IAIN maupun UIN, maka dapat disampaikan prodi agama yang langka peminat yaitu Prodi Studi Agama-Agama Fakultas Syariah dan Hukum, Prodi Pengembangan Masyarakat Islam Fakultas Dakwah dan Komunikasi, Prodi Aqidah dan Filsafat Islam Fakultas Ushuludin dan Filsafat, Prodi Perbandingan Mazhab Fakultas Syariah dan Hukum, dan Diploma III Ilmu Perpustakaan Fakultas Adab Humaniora.

\section{F. CIPP PADA PRODI AQIDAH DAN FILSAFAT ISLAM}

\section{Context}

Hadirnya Prodi Aqidah dan Filsafat Islam menentukan lahirnya IAIN Ar Raniry Banda Aceh. Prodi Aqidah dan Filsafat Islam berdiri berdasarkan Surat Keputusan Direktur Jenderal Bimas Islam No. KPP/D.VI/718/74, tanggal 23

Desember 1974 tentang Jurusan-Jurusan pada Fakultas di Lingkungan Institut Agama Islam Negeri (IAIN). Selanjutnya pada tanggal 28 Januari 2014 diterbitkan Surat Keputusan Direktur Jenderal Pendidikan Islam No. 442 Tahun 2014 tentang Perpanjangan Izin Penyelenggaraan dan Penyesuaian Nomenklatur Program Studi Pada Program Sarjana Universitas Islam Negeri $\mathrm{Ar}$ Raniry Darusalam Banda Aceh dari Prodi Aqidah dan Filsafat menjadi Prodi Ilmu Aqidah. Dalam perkembangannya diterbitkan SK Direktur Jenderal Pendidikan Islam No. 6943 Tahun 2016 tentang Perubahan dan Penyesuaian Nomenklatur Program Studi Perguruan Tinggi Keagamaan Islam (PTKI) dari Prodi Ilmu Aqidah menjadi Prodi Aqidah dan Filsafat Islam.

\section{Input}

Input mahasiswa Prodi Aqidah dan Filsafat berasal dari lulusan Madrasah Aliyah sebanyak 27,02\%; SMA sebanyak $51,35 \%$ SMK sebanyak $8,10 \%$ dan Pondok Pesantren sebanyak 13,51\%.

Adapun jumlah Dosen di Prodi Aqidah dan Filsafat Islam seluruhnya berjumlah 14 orang terdiri dari satu guru besar/Profesor yaitu Prof Dr. Syamsul Rijal; Sepuluh Doktor yaitu: Dr. T. Safir Iskandar Wijaya, M.A; Dr. Damanhuri Basyir, M.Ag.; Dr. Lukman Hakim M.Ag.; 
Dr. Husna Amin; M.Ag.; Dr. Juwaini Saleh, M.Ag.; Dr. Fuad Ramly, S.Ag. M.Hum; Dra. Suraiya I.T.M.A. Ph.D.; Dr. Ernita Dewi, S.Ag. M. Hum.; DR. Nurkhalis, S.Ag. S.E, M.Ag.; Dr. Faizal Muhammad Nur, Lc., M.A.; dan tiga kandidat doktor yaitu: Syarifuddin, S.Ag. M.Hum.; Zuherni Abdullah, M.Ag. dan Happy Saputra, M.Fil.I. Sedangkan staf administrasi 1 orang (Arif Gunandar, S.Ud.).

Adapun struktur organisasi Prodi Aqidah dan Filsafat Islam terdiri Dekan: Drs. Fuady, M.Hum.; Wakil Dekan 1: Dr. Abdul Wahid, M.Ag.; Wakil Dekan 2: Muhammad Zaini, M.Ag.; Wakil Dekan 3: Syarifuddin, S.Ag, M.Hum.; Kaprodi: Happy Saputra, S.Ag., M.Phil.I.; dsn Sekretaris Prodi: Syarifuddin, S.Ag, M.Hum.

\section{Process}

Sistem perkuliahan Prodi Aqidah dan Filsafat Islam melalui kegiatan Intra Kurikuler, Kokurikuler, dan Ekstrakurikuler. Kegiatan Intrakurikuler merupakan kegiatan yang dilakukan oleh Prodi Aqidah dan Filsafat Islam yang sudah teratur, jelas. dan terjadwal secara sistematik yang merupakan program utama perkuliahan dalam proses mendidik mahasiswa. Kegiatan Kokurikuler adalah kegiatan yang menunjang dan membantu kegiatan intrakurikuler biasanya dilaksanakan di luar jadwal intrakurikuler dengan maksud agar mahasiswa lebih memahami dan memperdalam materi yang ada di intrakurikuler, biasanya kegiatan ini berupa penugasan atau pekerjaan rumah ataupun tindakan lainnya yang berhubungan dengan materi intrakurikuler yang harus diselesaikan oleh mahasiswa. Sedangkan kegiatan Ekstrakurikuler adalah kegiatan yang dilaksanakan di luar jam perkuliahan (di luar intrakurikuler), dan kebanyakan materinya pun di luar materi intrakurikuler, yang fungsi utamanya untuk menyalurkan/mengembangkan kemampuan siswa sesuai dengan minat dan bakatnya, memperluas pengetahuan, belajar bersosialisasi, menambah keterampilan, mengisi waktu luang, dan lain sebagainya.

Strategi perkuliahan dilaksanakan dengan menggunakan berbagai strategi dan teknik yang mendorong mahasiswa untuk berpikir kritis bereksplorasi, berkreasi, dan bereksperimen dengan memanfaatkan berbagai sumber pembelajaran. Di Prodi Aqidah dan Filsafat Islam pelaksanaan proses pembelajaran umumnya dilakukan di dalam ruangan kelas.

Adapun metode perkuliahan yang dikembangkan dosen Prodi Aqidah dan Filsafat Islam melalui: a) Metode tatap muka di dalam kelas, metode ini dilakukan 


\section{Eksistensi Prodi Agama Langka Peminat...}

pada setiap perkuliahan, hal ini dimaksudkan untuk memberikan teori pendukung bagi mahasiswa, agar dapat memahami, dan mengetahui hal-hal yang berkaitan dengan mata kuliah yang diberikan. b) Metode diskusi, metode ini digunakan dalam waktu-waktu tertentu dengan topik tertentu, metode ini dimaksudkan untuk meningkatkan pemahaman para mahasiswa terhadap teori yang diberikan dan masalah yang dihadapi sesuai dengan topik yang didiskusikan. c) Tugas mandiri maupun kelompok, pemberian tugas mandiri maupun kelompok diberikan kepada mahasiswa sebagai sarana latihan untuk menyelesaikan berbagai persoalan secara mandiri maupun kerjasama tim yang hasilnya dapat menjadi feed back bagi dosen. d) Praktik Pengalaman Lapangan (PPL), PPL diaplikasikan dalam bentuk praktik mengajar dan kegiatan edukasional lainnya di lembaga sekolah. PPL yang dilakukan mahasiswa merupakan salah satu wadah agar mahasiswa mendapatkan pengalaman profesi yang dapat diandalkan. Dalam PPL mahasiswa akan dihadapkan pada kondisi riil aplikasi bidang keilmuan, seperti: kemampuan mengajar, kemampuan bersosialisasi dan bernegosiasi, serta kemampuan manajerial kependidikan lainnya. Setiap dosen dalam perkuliahan diwajibkan membuat Silabus dan SAP (Satuan Acara Perkuliahan). Sedangkan kegiatan ekstrakurikuler umumnya dikelola oleh Mahasiswa dengan bimbingan dosen dalam bentuk kegiatan pengajian, halaqah, ta'lim/tahsin, belajar di Mahad tentang Bahasa Arab, Bahasa Inggris, kepribadian, dan enterpreneurship.

Pengabdian masyarakat Prodi Aqidah dan Filsafat Islam dilakukan melalui KPM (Kuliah Pengabdian Masyarakat); Baksos; Safari Ramadhan; kegiatan sosial sesuai dengan kejadian di masyarakat seperti: membantu bencana alam yang dilakukan oleh Dosen dan Mahasiswa.

Dalam kegiatan penelitian dosen dibantu Mahasiswa. Mahasiswa dalam hal ini diposisikan sebagai pembantu peneliti sedangkan Dosen sebagai ketua penelitian. Penelitian untuk Dosen dibiayai melalui Lembaga Penelitian (satu tahun satu kali per dosen yang lulus seleksi) melalui penelitian individual, kolaborasi, dan penelitian prodi Sedangkan dari lembaga lain tergantung dosen masing-masing

Sedangkan untuk penyelesaian tugas akhir, mahasiswa wajib mendaftar ke prodi setelah melengkapi semua persyaratan dilanjutkan sidang munaqasyah skripsi. Prodi mengagendakan jadwal sidang dan penetapan dewan penguji dengan berkonsultasi dengan Wakil Dekan 1; pelaksanaan sidang sampai tuntas. 
Tahapan penyelesaian tugas akhir mahasiswa wajib mengikuti ujian komprehensif dan munaqasyah skripsi berdasarkan SOP Ujian Komprehensif dan SOP Munaqasyah Skripsi.

\section{Product}

Jumlah alumni Prodi Aqidah dan Filsafat Islam terhitung sejak tahun 2008 seluruhnya berjumlah 168 orang. Mereka bekerja sebagai karyawan di Kemenag, TNI dan Polri (penyidik Polda), penyuluh agama, anggota dewan, pemerintahan daerah, interpreneurship, wartawan, penulis dan mejadi ustadz. Bagi pengguna alumni terhadap kinerja dan integritas alumni Prodi Aqidah dan Filsafat Islam umumnya sangat positif, mereka dapat bekerja secara baik, loyal, dan dapat bekerja sama secara tim meskipun mereka tidak memiliki skil khusus tetapi umumnya mereka mudah untuk beradaptasi di lingkungan kerjanya. ${ }^{13}$

Prodi Aqidah dan Filsafat Islam belum memiliki Jurnal, sampai saat ini masih bergabung dengan jurnal di Fakultas Ushuludin, yaitu: Jurnal Subtantia dan Jurnal Muasiroh. Jumlah artikel dalam jurnal minimal 9 (sembilan) artikel. Dosen wajib membuat 2 (dua) artikel dalam setiap tahunnya. Sedangkan untuk alumni minimal 1 artikel yang bersumber dari skripsi.

\footnotetext{
${ }^{13}$ Happy Saputra. (2018). Ketua Prodi Aqidah dan Filsafat Islam UIN Ar Raniry Banda Aceh.
}

Penghargaan yang diperoleh Prodi Aqidah dan Filsafat Islam sampai saat ini belum ada namun untuk penghargaan para dosen dan mahasiswa sudah ada yaitu dalam bentuk penghargaan lomba maupun kegiatan lainnya. Seperti: dosen terbaik, dosen favorit, dosen teladan, lomba seni dan olah raga bagi mahasiswa, seperti lomba pidato, lomba kaligrafi, dan olahraga.

Alumni Prodi Aqidah dan Filsafat Islam yang menjadi tokoh masyarakat, politik dan birokrat di antaranya: Prof. Dr. Ahmad Daudi sebagai tokoh masyarakat Aceh; Prof. Dr. Syamsul Rijal, M.Ag., sebagai penceramah masjid Raya Aceh; Dr. Damanhuri, M.Ag, sebagai tokoh masyarakat, penulis, dan penceramah; Dr. Lukman Hakim, M.Ag. sebagai tokoh masyarakat, peneliti, dan penulis dan Dr. Faisal Muhamad Noor, Lc, M.A. sebagai tokoh tasawuf.

\section{G. ANALISIS}

Keberadaan Perguruan Tinggi Keagamaan Islam (PTKI) semakin menjadi pilihan bagi para calon mahasiswa yang ingin melanjutkan pendidikan ke jenjang perguruan tinggi. Seiring dengan perubahan IAIN menjadi UIN mendorong minat masyarakat untuk masuk UIN lebih tinggi terutama pada prodi umum seperti pada Fakultas Hukum, Ekonomi, 


\section{Eksistensi Prodi Agama Langka Peminat...}

Psikologi, Kedokteran dan lain-lain. sementara untuk program studi agama murni seperti Program Studi Studi AgamaAgama/Perbandingan

Agama,

Perbandingan Mazhab, Aqidah dan

Filsafat Islam, Ilmu Pengembangan Masyarakat Islam sangat kurang peminatnya. Salah satu alasannya karena tidak jelasnya lapangan pekerjaan setelah mereka menyelesakan studinya. Ini berbeda dengan prodi agama yang memiliki kaitan dengan dunia kerja masih sangat diminati, seperti jurusan Pendidikan Agama Islam (PAI), Jurusan Ekonomi Syariah/Perbankan Syariah yang mengalami kenaikan dalam setiap tahunnya.

Perubahan IAIN menjadi UIN mengakibatkan terpinggirkannya program studi agama kalah bersaing dengan program studi yang mempelajari bidang keilmuan umum. Dengan kata lain, sekalipun UIN dapat menjaring banyak mahasiswa, tetapi mayoritas mahasiswa memilih program studi yang umum dan hanya sedikit yang memilih program studi agama, apalagi program studi yang mengkaji keilmuan agama murni. Jika ini terjadi, maka akan mengerdilkan keilmuan agama yang pada awalnya menjadi tugas utama sebelum adanya perubahan bentuk institusi.
Berdasarkan data jumlah peminat calon mahasiswa pada berbagai program studi agama UIN Ar Raniry Banda Aceh, prodi yang mengalami langka peminat adalah Prodi Aqidah dan Filsafat Islam Fakultas Ushuludin dan Filsafat selain Prodi Studi Agama-Agama Fakultas Syariah dan Hukum, Prodi Pengembangan Masyarakat Islam Fakultas Dakwah dan Komunikasi, Prodi Perbandingan Mazhab Fakultas Syariah dan Hukum dan Diploma III Ilmu Perpustakaan Fakultas Adab Humaniora.

Prodi Aqidah dan Filsafat Islam UIN Ar Raniry Banda Aceh berdiri berdasarkan Surat Keputusan Direktur Jenderal Bimas Islam Nomor: KPP/D.VI/718/74, tanggal 23 Desember 1974 tentang JurusanJurusan Pada Fakultas di Lingkungan Institut Agama Islam Negeri (IAIN). Selanjutnya pada tanggal 28 Januari 2014 diterbitkan Surat Keputusan Direktur Jenderal Pendidikan Islam No. 442 Tahun 2014 tentang Perpanjangan Izin Penyelenggaraan dan Penyesuaian Nomenklatur Program Studi Pada Program Sarjana Universitas Islam Negeri Ar Raniry Darusalam Banda Aceh dari Prodi Aqidah dan Filsafat menjadi Prodi Ilmu Aqidah. Dalam perkembangannya diterbitkan SK Direktur Jenderal Pendidikan Islam No. 6943 Tahun 2016 tentang Perubahan dan Penyesuaian 
Nomenklatur Program Studi Perguruan Tinggi Keagamaan Islam (PTKI) dari Prodi Ilmu Aqidah menjadi Prodi Aqidah dan Filsafat Islam.

Meskipun Prodi Aqidah dan Filsafat Islam langka peminat perlu dikemas sedemikian rupa agar mahasiswa, selain mendapatkan ilmunya juga mendapatkan keterampilan lain yang menunjang saat memasuki dunia kerja. Ia menilai, sedikitnya peminat prodi keagamaan di PTKIN karena calon mahasiswa masih memiliki pola pikir yang cenderung pragmatis. "Prodi keagamaan dianggap tidak relevan dengan kebutuhan dunia kerja saat ini". Dan perlu dilakukan upayaupaya agar prodi keagamaan di PTKIN kembali diminati para calon mahasiswa. Salah satu caranya adalah perguruan tinggi harus lebih kreatif dan inovatif. Di samping itu, pada prodi langka peminat perlu melakukan sosialisasi, pelayanan lebih baik menjadi instrument utama daya tarik mahasiswa. PTKI sebagai unit usaha yang bergerak di bidang jasa, maka pelayanan yang baik adalah keniscayaan. Penyediaan dosen yang kompeten, alokasi jam yang tepat, penguatan disitingsi keagamaan, jaminan mutu, dan lain-lain.

Bagi prodi langka peminat seperti Aqidah dan Filsafat Islam, besarnya jumlah mahasiswa tidak penting. Yang penting adalah mahasiswa prodi Aqidah dan Filsafat Islam memiliki kualitas. Tetapi karena tuntutan IKU, maka prodi mencari alternatife untuk menambah jumlah mahasiswa. Menghadapi prodi langka peminat maka perlu: 1) Adanya kebijakan rektor dan dekan meluluskan mahasiswa yang tidak diterima pada prodi lain dengan standar nilai lulus universitas untuk masuk pada prodi AFI; 2) Adanya sosialisasi jurusan agama pada siswa MA, SMA, dan SMK dan pesantren yang melibatkan para alumni, dosen, tenaga pendidik dan tokoh masyarakat; 3) Kegiatan magang mahasiswa ke instansi pemerintah dan non pemerintah yang relevan dengan prodi AFI; 4) MoU antara Prodi AFI dengan lembaga pemerintah dan swasta; dan 5) Silaturahmi stakhholders dengan komponen yang ada di prodi AFI.

\section{H. KESIMPILAN}

1. Program studi agama langka peminat di UIN Ar Raniry Banda Aceh adalah Prodi Studi Agama-Agama Fakultas Syariah dan Hukum, Prodi Pengembangan Masyarakat Islam Fakultas Dakwah dan Komunikasi, Prodi Aqidah dan Filsafat Islam Fakultas Ushuludin dan Filsafat, Prodi Perbandingan Mazhab Fakultas Syariah dan Hukum dan Diploma III Ilmu Perpustakaan Fakultas Adab Humaniora. 


\section{Eksistensi Prodi Agama Langka Peminat...}

2. Prodi Aqidah dan Filsafat Islam UIN Ar Raniry lahir berdasarkan Surat Keputusan Direktur Jenderal Bimas Islam No. KPP/D.VI/718/74, tanggal 23 Desember 1974; Surat Keputusan Direktur Jenderal Pendidikan Islam No. 442 Tahun 2014 tanggal 28 Januari 2014 dan SK Direktur Jenderal Pendidikan Islam No. 6943 Tahun 2016 tertanggal 7 Desember 2016 Tentang Perubahan dan Penyesuaian Nomenklatur Program Studi Perguruan Tinggi Keagamaan Islam (PTKI) dari Prodi Ilmu Aqidah menjadi Prodi Aqidah dan Filsafat Islam.

3. Strategi perkuliahan dilaksanakan dengan menggunakan berbagai strategi dan teknik yang mendorong mahasiswa untuk berpikir kritis, bereksplorasi, berkreasi, dan bereksperimen dengan memanfaatkan berbagai sumber pembelajaran yang tersedia. Metode perkuliahan yang dikembangkan adalah: a) Metode tatap muka di dalam kelas, b) Metode diskusi, c) Tugas mandiri maupun kelompok. dan d) Praktik Pengalaman Lapangan (PPL).

4. Alumni Prodi Aqidah dan Filsafat Islam bekerja sebagai karyawan di Kemenag, penyuluh agama, anggota dewan aparatur, pemerintahan daerah, TNI dan Polri, interpreneurship, wartawan, penulis dan menjadi ustadz. Di antara mereka ada yang menjadi tokoh masyarakat, tokoh dan birokrat.

5. Bagi prodi langka peminat seperti Aqidah dan Filsafat Islam, besarnya jumlah mahasiswa tidak penting; yang penting adalah mahasiswa prodi Aqidah dan Filsafat Islam memiliki kualitas.

\section{REKOMENDASI}

1. Kementerian Agama harus tetap mempertahankan program studi keagamaan langka peminat di PTKI.

2. Perlu langkah-langkah strategis dan teknis pada program studi Aqidah dan Filsafat Islam (AFI), melalui:

a. Kebijakan Rektor dan Dekan untuk meluluskan mahasiswa yang tidak diterima pada prodi lain dengan standar nilai lulus untuk masuk pada prodi langka peminat.

b. Kebijakan Rektor untuk membuka jalur khusus "prestasi science, seni, dan olahraga" bagi mahasiswa pada prodi langka peminat.

c. Memberdayakan dosen, tokoh masyarakat, dan alumni untuk mensosialisasi program studi agama-agama pada siswa MA, SMA, SMK, dan Pondok Pesantren.

d. Adanya MOU lapangan pekerjaan antara UIN dengan pemerintah 
daerah terhadap alumni pada prodi langka peminat.

e. Memberikan bea siswa kepada mahasiswa pada prodi sepi peminat.

3. Prodi AFI harus lebih kreatif dan inovatif mensosialisasikan programnya kepada siswa MA, SMA, SMK, dan Pondok Pesantren dengan melibatkan alumni, dosen, dan tohkoh masyarakat.

4. Karena tuntutan Indikator Kinerja Utama (IKU), maka prodi Aqidah dan Filsafat Islam UIN Ar Raniry Aceh harus mencari berbagai alternatife untuk menambah jumlah mahasiswa dalam setiap tahunnya.

\section{DAFTAR PUSTAKA}

Andra, P. (2014). Landasan dan Prinsipprinsip Pengembangan Kurikulum.http/andraputra.blogspot.co .id diakses pada Tanggal 20 Juli 2017.

Buku Pedoman Akademik UIN Ar Raniry Aceh Tahun 2018

Harahap, N. et.al, (1991). Wawasan Almamater IAIN Sunan Kalijaga Yogyakarta Yogyakarta: Panitia Penyelenggara Penataran P-4 100 Jam Gaya Baru IAIN Sunan Kalijaga.

Hamalik, O. (2008). Manajemen Pengembangan Kurikulum Bandung: PT Remaja Rosdakarya.

Konsep Manajemen Pendidikan Kumpulan Makalah \& Artikelhttps: //makalahibnu.blogspot.com/2010/01/ konsep- manajemen pendidikan.html \#ixzz5 UDa Enf5h.
Kurniadin, D. dan Machali, I. (2012). Manajemen Pendidikan Konsep dan Prinsip Pengelolaan Pendidikan. Jogjakarta: Ar-Ruzz Media.

Margono, S. (2004). Metodologi Penelitian Pendidikan. Jakarta: Rineka Cipta.

Meleong, L.J. (2011). Metodologi Penelitian Kualitatif. Penerbit: PT Remaja Rosdakarya. Bandung.

Syam, N. Menyeimbangkan Prodi Agama dan umum, http://nursyam.uinsby.ac.id/?p=832.

Olivia, F. (1992). Developing The Curriculum. Publisher: New York.Herper Collins.

Raharjo, R. (2010). Inovasi Kurikulum Pendidikan Agama Islam. Yogjakarta: Magnum Pustaka.

Rchardus, D. dan Rchardus Eko, I. (2004). Manajemen Perguruan Tinggi Modern, Jakarta: Atma Jaya dan Perbanas.

Statistik Pendidikan Islam tahun 2014/2015. Direktorat Pendidikan Tinggi Islam Kementerian Agama RI.

Undang-Undang Nomor 20 Tahun 2003 tentang Sistem Pendidikan Nasional.

Undang-Undang Nomor 12 Tahun 2012 tentang Sistem Pendidikan Tinggi.

UU No. 20/2003 tentang Sisdiknas, dan PP RI No. 17/2010 tentang Pengelolaan dan Penyelenggaraan Pendidikan.

Puslitbang Penda, (2013). Eksekutif Summary Penelitian Pemetaan Kapasitas 6 UIN. Jakarta: Balitbang Kemenag.

Puslitbang Penda. (2013). Laporan Penelitian Kapasitas 6 UIN. Jakarta: Balitbang Kemenag.

Permenristekdikti nomor 44 tahun 2015, tentang Standar Penyelenggaraan Pendidikan Tinggi. 


\section{Eksistensi Prodi Agama Langka Peminat...}

PMA No. 37 Tahun 2017, Perubahan atas Peraturan Menteri Agama Nomor 33 Tahun 2016 tentang Gelar Akademik Perguruan Tinggi Keagamaan. https://dinarpratama.wordpress.com/2010/ 11/20/ model-evaluasi-cipp-contextinput-process-product/. Diakses pada Tanggal 18 Oktober 2018. 